\title{
MAXIMIZING SOCIAL ASSOCIATION ACTIVITIES AS A PLACE OF DA'WA FOR WOMEN
}

\author{
Ahmad Luthfi Hidayat \\ Cirebon Islamic Institute \\ 2014luthfi@gmail.com
}

\begin{abstract}
Islam is a religion that is believed by Muslims as a religion that always calls for goodness. It is based on what has been brought and taught by the Prophet Muhammad SAW to Muslims. The presence of the Prophet among mankind as a role model and carrying a noble mission one of them is to perfect good morals. Moral problems are actually human problems from ancient times until now. To overcome these moral problems, some ulama have made their best efforts to convey messages of kindness. However, often some ulama found a little problem related to the target of the $d a^{\prime} w a$ they were to convey. Da'wa is sometimes only conveyed to certain groups most of whom are male, so that some of the women are still not touched by the $d a^{\prime} w a$. For this reason, many ulama try to establish a special place to convey their preaching to be more optimal. This special place is often referred to as social association (jam'iyah). In this jam'iyah place, there are usually many Islamic activities held where many of the women are present in order to gain a series of knowledge. That way, the religious activities contained in this jam'iyah, In the end, it was used as a place for delivering da'wa among the targets were women. This research will describe $d a$ 'wah activities for women through jam'íyah activities. This study aims to maximize jam'íyah activities for da'wa. This research will be conducted using a qualitative descriptive method.
\end{abstract}

Keywords: Maximizing; social association; jam'īyah; women; da'wa.

\begin{abstract}
Abstrak: Islam merupakan agama yang diyakini oleh umat Islam sebagai agama yang senantiasa menuntut kebaikan. Salah satu bentuk kebaikan adalah memiliki akhlak baik. Masalah moral sebenarnya adalah masalah manusia dari dulu. Untuk mengatasi masalah akhlak, beberapa ulama telah berusaha untuk menyampaikan pesan-pesan kebaikan. Namun seringkali sebagian ulama menemukan sedikit kendala terkait dakwah yang hendak mereka sampaikan. Dakwah terkadang hanya disampaikan kepada kelompok tertentu yang sebagian besar adalah laki-laki, sehingga sebagian perempuan masih belum tersentuh dakwah. Untuk itu, banyak ulama yang berusaha mendirikan tempat khusus untuk menyampaikan dakwahnya agar lebih maksimal. Tempat istimewa ini sering disebut sebagai jam'iyah. Di tempat jam'iyah ini biasanya banyak diadakan kegiatan keislaman dimana banyak perempuan hadir untuk menimba ilmu. Dengan begitu, kegiatan keagamaan yang terkandung dalam jam'íyah ini, pada akhirnya digunakan sebagai wadah dakwah yang salah satu sasarannya adalah perempuan. Penelitian ini akan mendeskripsikan kegiatan dakwah perempuan melalui kegiatan jam'íyah. Penelitian ini bertujuan untuk memaksimalkan kegiatan jam'iyah untuk dakwah. Penelitian ini akan dilakukan dengan menggunakan metode deskriptif kualitatif.
\end{abstract}

Kata kunci: Maksimal; aosiasi sosial; jam'iyah; perempuan; dakwah. 


\section{A. Introduction}

Allah swt has sent down Islamic law on this earth with the aim of all the benefit and all the good of mankind as the khalifah on this earth. ${ }^{1}$ The Islamic Sharia was brought by the prophet Muhammad saw through the angel Jibril. The Islamic Sharia itself basically includes matters relating to worship (ibadah), mu'amalah and also morals (akhlak). These three things in principle will lead to how a human being can worship properly to Allah swt. All humans as creatures of Allah swt of course you have a big obligation that is, always worship to Allah swt as long as he lives on this earth.

Worship which is part of the main human obligation of course given to men and women. That way in Islamic teachings there is no term compilation of the obligations of worship only for certain people. Men and women all have the same degree in the sight of Allah swt, and all of them are obliged to continue to worship Allah swt throughout their life. Both men and women also have the right to get the maximum reward possible from Allah swt.

The obligation to worship Allah swt must of course be in accordance with the teachings of Islam that have been taught by the prophet Muhammad saw. The teachings of this prophet have actually been conveyed to mankind, especially Muslims, to be practiced in everyday life. Here the importance of a person to learn and demand knowledge as much as possible as a provision and as a guide for him in carrying out the commands of Allah Swt. Besides that, of course, Muslim scholars should continue to teach and call on Muslims to always study Islamic law and practice it in their daily lives.

In terms of calling, inviting and $d a^{\prime} w a$ to Muslims, a number of Muslim scholars actually call and preach to all people without having to specialize in certain people. Because Islamic teachings must be conveyed to anyone and should not be owned by certain people. Islamic teachings should be conveyed to the young and old, the children and adolescents, and the men and women. All of these people have the right to obtain Islamic knowledge through the medium of $d a^{\prime} w a h$ conveyed by Islamic scholars. All of that is certainly something that differentiates Islamic teachings from other teachings besides Islam.

If we try to look a little at the history of mankind in the past, at least we will find many things that lead to injustice. One of the reasons for this injustice and inequality is the specialization of certain people rather than others. For example, there is an inequality between men and women in many ways where in the end women are always humiliated and not given their rights like what men accept.

All this injustice and inequality between men and women is certainly not present in Islamic teachings. Islam has glorified women in many ways. In Islam, women have the same rank as men. Both men and women all have the right to gain knowledge, both of them also have the same obligation with Allah swt, which is always obliged to serve and worship Allah swt.

However, it is often heard in society that women cannot be equated with men in many ways. So, the appropriate place for women is to stay in the house and not be allowed to do much activity outside the house. Thus, the lives of women in their daily lives are not far from activities in the home. Women are viewed by some in society as inappropriate to work outside the home. Women also do not deserve what men get. Until in the end, women were not given the slightest opportunity to just gain knowledge and listen to lectures and $d a^{\prime} w a$ from muslim scholars, because of the excessive concern that there would be a mixture of men and women.

All the prohibitions directed at women regarding their activities outside the home of course at least will result in the preaching of Islam not reaching them. It is feared that women will not have the correct Islamic teachings so that in the end they will perform activities of worship to Allah swt incorrectly and not in accordance with Islamic teachings, while worshiping Allah swt is an obligation that must be done by anyone, both men- men and women. To overcome this, a number of muslim scholars tried to make a lot of efforts so that the da'wa of Islam reached women. One of the efforts made by muslim scholars is to establish a special place

${ }^{1}$ Abdul Karim Zaidan, Ușul al-Da'wah (Beirut: Muassasah al-Risalah, 2001), 301. 
known by the community as jamiyyah. In this jamiyyah place, the delivery of Islamic da'wa will be maximized in the form of worship guidance and mu 'amalah to women.

\section{B. Theoretical Review}

The discussion about da'wa is the discussion most often studied and discussed by many scholars, even more so by Muslim scholars. The word $d a^{\prime} w a$, when viewed from the language point of view, means a call or it can also mean an invitation. $D a^{\prime} w a$ is an Arabic lafadz that comes from lafadz da'a yad'u da'watan. If there is the sentence Muhammad yad'u shohibahu means Muhammad is calling his friend. Thus, it is clear that the word $d a^{\prime} w a$ when interpreted in language means to invite or to call.

While the word $d a^{\prime} w a$ itself when interpreted in terms, then $d a^{\prime} w a$ can be interpreted as a form of invitation or call addressed to anyone to do something good in the form of a set of commands from Allah swt and also invites every human being to always leave and abstain from bad deeds or keep away from all the prohibitions that have been made by Allah swt and His Messenger. ${ }^{2}$ From the explanation of the definition of $d a^{\prime} w a$, many Muslim scholars simplify the meaning of da'wa to a form of al-amr bi al-ma'ruf wa al-nahy 'an al-munkar which the Indonesian Muslim community often calls amar ma'ruf-nahy munkar. ${ }^{3}$

Amr ma'ruf-nahy munkar is important to be implemented for every Muslim in order to remind each other of worship and also to remind each other of all forms of goodness that exist in Islamic teachings. Thus, with this call in the form of $d a^{\prime} w a$, it is hoped that everyone, especially the Muslim community, will always start learning and understanding the teachings of Islam brought by the Prophet saw as well as possible. By studying and understanding the teachings of Islam, it is hoped that every Muslim can practice it in his daily life by continuing to imitate what was done by the Prophet Muhammad saw. From this, it is very clear that the $d a^{\prime} w a$ target includes all people from young children to adults, from young people to the elderly, and even the target of $d a^{\prime} w a$ also for men to women.

$D a^{\prime} w a$ addressed to women are no less important than $d a^{\prime} w a$ addressed to men. In Islamic teachings, women have rights that cannot be distinguished from men. They also have the right to get an understanding of the teachings of Islam through the $d a^{\prime} w a$ chants delivered by the $d a^{\prime} i$ at any time and place. Conveying $d a^{\prime} w a$ to women often encountered obstacles regarding their proper place. Obstacles in the delivery of $d a^{\prime} w a$ to women at least began to get a little light with the emergence of many jam'iyah in the Muslim community with all forms of activities that exist in it.

Jam'iyah itself actually comes from the word jama'a yajma'u jam'an which means to collect. Thus, jam'íyah can at least mean as an association of many people to carry out many activities related to the practice of Islamic teachings. Jam'íyah is often found in society as a gathering place for many people, especially women to gain a lot of knowledge and as a place for women's friendship. With many gatherings of women in this jam'iyah place, in terms of delivering da'wa material to women it will be very easy and can be conveyed continuously.

\section{Methods}

This study is deliberately written to explain the importance of delivering $d a^{\prime} w a$ material for women. Women who are actually glorified by Islamic teachings, it turns out that in practice in the field there are often various imbalances of rights and inequality of justice that occur among women. Da'wa material should also be given to women in order to obey Allah swt through continuous practicing of worship. This study will also convey the importance of a place devoted to women so that da'wa material continues to be conveyed to women. In fact, this special place for women has appeared in the Muslim community as jam'iyah. That way the place

\footnotetext{
2 Syalby, Ro'uf. Al-Da'wah al-Islamiyyah fi 'Ahdihäal-Makkīy (Al-Dauhah: Dar al-Qalam, 1982), 22.

${ }^{3}$ Ahmad, Abdul Aziz. "Dakwah, Seni dan Teknologi Pembelajaran." Jurnal Dakwah Tabligh, n.d. p.: 76.
} 
of jam'íyah occupies an important position for women in order to fully absorb Islamic teachings to them. Therefore, through this study, it will also explain the need to maximize jam'iyah activities in the Muslim community as a place for gathering and as a place to convey da'wa to women.

To explain this study, the method used in this study is to use a qualitative descriptive method. This descriptive method is used to examine and also at the same time describe all matters related to Islamic activities carried out by jam'iyah in Muslim communities. With this method we will also discuss the importance of delivering $d a^{\prime} w a$ to women where they are also Allah's creatures who have the duty to serve Allah swt. With this qualitative descriptive method, it will also explain the importance of maximizing jam'íyah activities as a special place to convey da'wa to women.

\section{Results and Discussion}

The terms discrimination and the superiority of one people over another will never be known and are not taught in Islamic teachings. The Prophet Muhammad saw always conveyed to Muslims that all human beings created by Allah swt actually have the same rank. ${ }^{4}$ The difference between human beings will be seen from the level of one's devotion to the Creator of Allah swt. With this equality among humans, of course everyone will continue to compete for goodness. This is reflected in Allah's commandment, namely fastabiqu al-khayrat. ${ }^{5}$ This simple command from Allah swt forces all mankind to continue to compete in goodness for the sake of gaining a glorious place with Allah swt. Competition in terms of goodness is carried out by every group, be it men or women.

In terms of competition for this goodness, as Allah swt has commanded in His Word, sometimes women have a narrower space for movement when compared to men. The narrow space for women is due to many factors, both internal and external. Regardless of the factors that exist, in principle, women in society are often not given the freedom to carry out many activities to gain reward and goodness as taught in Islamic teachings. Women are seen by some people as people who do not need as much movement as men do.

With the limited space for women, it is feared that there will be inequality and injustice in terms of rights and obligations. Women created by Allah swt are actually part of the complement of men. So the teachings of Islam always teach the importance of equal distribution of rights and responsibilities. All things that lead to social inequality are actually things that are not part of Islamic teachings. Thus, the true rights and obligations must be equalized, both men and women. If the equal rights and obligations have really been implemented, then women have the right to many things as accepted by men.

Women have the right to get as much knowledge as possible through teaching and learning activities. They also have the right to understand Islamic teachings properly and correctly. In principle, this Islamic teaching concerning equal rights and obligations for men and women is understood by everyone. It's just that it is often found that women are not very flexible in their activities and in many ways. This includes the delivery of Islamic teachings through da'wa material, these women are sometimes left untouched.

A Group of Muslim scholars saw that the material of $d a^{\prime} w a$ was very important to be conveyed to women. It's just that to gather a large number of women for the sake of conveying da'wa material to them is considered quite difficult and a bit troublesome. It is very different when trying to round up a large number of men. To solve this problem, in the end many Muslim scholars made an effort by establishing many jam'íyah in society which were designated for women. In principle, the existence of jam'iyah would be used as a place for a large number of

\footnotetext{
${ }^{4}$ al-Siba'y, Musthafa bin Husni. Al-Mar'ah bayn al-Fiqh wa al-Qānūn (Beirut: Dar al-Waraq li al-Nashr wa al-Tawzi', 1999), 23.

5 al-Razy, Fakhruddin. Al-Tafsir al-Kabir, Vol. 4. (Beirut: Dar Ihya' al-Turath al-Arabiy, 2000), 114.
} 
women to gather. The effort to establish jam'íyah was seen as quite successful. This is evidenced by the always busy activities carried out by jam'iyah for women.

With this special place for women called jam'íyah, women will not feel confused and also will not feel inconvenient for activities in order to gain knowledge about Islamic teachings in all its models and forms. It is also very easy for Islamic scholars to convey da'wa material to women through jam'iyah activities in the community. Through this jam'iyah, at least the da'wa will be conveyed properly to women as is often conveyed to men.

Therefore, the activities carried out by the jam'iyah in the midst of this community really need to be maintained, and preserved, so that women will always continue to get an understanding of Islam correctly through this jam'iyah activity. So, it is very important for Muslim scholars to maximize religious activities through this jam'iyah forum. Maximizing jam'iyah activities is considered important because jam'íyah activities have a huge influence in the delivery of da'wa, especially to women.

Regarding how and what is the best way to maximize Islamic activities in this jam'iyah for women, then of course at least for the first time they must understand correctly the important role of these jam'iyah activities. Besides that, it is very important to understand and know the important role of the existence of many jam'íyah in Muslim society. If all these things are understood and known, then at least it will be very easy to maximize the activity of jam'iyah as a place of da'wa for women.

Many things can be done by Muslim scholars to maximize the activities of jam'íyah. Among what can be done to maximize it is by making this jam'iiyah as a means of learning to read the Al-Qur'an. Lately, it is often found that our Muslim generation is not very good at reading the AlQur'an. Their busyness in world affairs, sometimes causes them to forget their holy book. They prefer to occupy themselves with matters that they consider more important to their lives. This of course causes them not to have enough time to just read the Al-Qur'an. There may even be some of them who forgot or purposely forgot the Al-Qur'an. Their tendency towards world affairs of course causes them to be less fluent in reading the Al-Qur'an. Therefore, through this jam'iyah activity, Muslim scholars can maximize it by teaching women how to read the al-Qur'an properly and of course correctly too.

By giving full attention to women through learning the Qur'an in this jam'iyah place, it is hoped that the goal of eradicating illiteracy of the Al-Qur'an can at least be achieved even though it is not yet at the level of true perfection. In order for women to be enthusiastic in learning to read the Al-Qur'an, Muslim scholars should explain to them the importance of learning the Qur'an. This is certainly in accordance with what was said by the prophet Muhammad saw and has been known by Muslims, namely: khayrukum man ta'allam al-Qur'an wa 'allamahu. ${ }^{6}$ By giving them a good understanding, they will be more eager to continue learning the al-Qur'an. This is all an effort to maximize jam'iyah activities with activities that are beneficial to women.

Among other things that can be maximized in jam'iyah activities in the Muslim community, namely by delivering the teaching of fiqh science to women. The jurisprudence in question is mainly related to discussion about taharah, discussion about salat, and discussion of other fiqh that will be of benefit to women. Fiqh learning is conveyed to them, because it involves the practice of worship which is carried out every day. One of the goals of learning jurisprudence is, of course, so that their worship is in accordance with Islamic teachings. Those are several things related to efforts to maximize jam'íyah activities as a place of preaching for women.

The tradition of learning to read the al-Quran in Indonesian society is a tradition that has been carried out for a long time. The tradition of reading the al-Quran was started by earlier Muslim scholars. The role of Muslim scholars in the past in teaching the reading of the al-Qur'an was very important, and in fact it was felt by the Indonesian Muslim community. The al-Qur'an, which is the holy book of Muslims, is very important to be introduced to the public, so that they

\footnotetext{
${ }^{6}$ al-Bukhory, Muhammad bin Isma'il Abu 'Abdillah. Sahih al-Bukhari. Vol. 6.9 vols (Damaskus: Dar Thouq al-Najah, 1422), 192.
} 
understand the importance of a holy book of the Qur'an. It is said to be important, because the holy book of the al-Qur'an contains teachings that are very important and relevant to human life.

Learning to read the al-Qur'an for the Indonesian Muslim community is seen as something that must be implemented from an early age. ${ }^{7}$ There is an opinion from the community, that among the benchmarks a person is good or bad, it can be seen how well someone is able to read the Al-Qur'an correctly. So, it often appears in the community, that education and learning of Islam, in practice in society, is learning the al-Qur'an. So, it is not surprising if one finds in the Indonesian Muslim community, many children go to a place of worship, call it a mosque or break, just to learn to read the al-Qur'an.

The spirit of learning to read the al-Qur'an in children, at least will have a good impact on them in adulthood. Childhood, which according to some people, is a period of play, it turns out that in Indonesian Muslim society, it can be accompanied by positive and useful activities, one of which is learning to read the al-Qur'an. Indonesian parents, consciously, they want their children to be classified as intelligent and pious children. One measure of piousness in the view of the Indonesian Muslim community is by looking at how well a child can practice reciting the AlQur'an.

It's just that good habits that are done when someone is still a child, sometimes it doesn't continue in adulthood or old age. Good habits, such as learning to read the Qur'an, don't seem to be continued when a person starts to grow up. For men, maybe this good habit can still be practiced, through several scientific studies conducted by a certain institution, or it can be obtained in a masjid, through a superior program offered by the masjid. That way, delivering $d a^{\prime} w a$ material to men seems easy enough, and can be done at any time, and in any event.

In the midst of Indonesian society, men seem to dominate almost all lines of social life. The existence of these superior men, of course, causes men to be able to do anything, be it something positive, or vice versa. In relation to something positive, men can worship freely. They can also gain knowledge anywhere. In short, they can receive a lot of $d a^{\prime} w a$ material from a Muslim scholar who has a broad and deep knowledge of Islam. That way, the scientific insights of men in society are increasing and increasing. Perhaps, the hope of the knowledge that these men have is that they can pass on their knowledge to others, such as to their families at home, especially to their wives who live in the house a lot every day. So that their families at home can also get knowledge, like that of men.

The delivery of $d a^{\prime} w a$ about Islamic teachings by men to their families at home should be needed and expected. The need for this da'wa material will be felt by women, most of whose activities are in the house. The knowledge of Islamic teachings that are owned by men, should be conveyed to their families at home, especially women. The women at home also need a touch of Islamic knowledge. The need for this knowledge, of course, will depend a lot on her husband as a man, which she can get a lot of knowledge, through a lot of studies about Islam outside the home.

The model of delivering da'wa from men to women in the house is, in principle, a good thing, and should be done continuously. But in fact, it is often found in society, that women really do not receive $d a^{\prime} w a$ material from anyone, including from their peers. So that the simplest knowledge of Islamic teachings such as reading the al-Qur'an, it is often found that women do not master it properly and correctly. Learning to read the al-Qur'an that was obtained when I was a child, is lost and only a few have made an impression. So that the al-Qur'an, which is the holy book of Muslims, is not so much touched by the Muslim community, especially women.

In order to avoid unfavorable situations, where women do not receive material da'wa about Islamic teachings perfectly, it is very necessary to find a way out. Many community leaders, and also many Muslim scholars think about this, in order to find the best solution, so that Islamic $d a^{\prime} w a$ can reach women. One of the best efforts made to convey Islamic teachings is to hold a special activity, which is often called jam'íyah activity.

\footnotetext{
${ }^{7}$ Syarifuddin, Ahmad, Mendidik Anak, Membaca dan Mencintai al-Qur'an (Jakarta: Gema Insani Press, 2004), 105.
} 
The existence of jam'íyah in Indonesian Muslim community, at first, was not much interested. Jam'iyah, in which there are many Islamic activities, is not widely known except by a few people. This is one of the reasons why the jam'iyah activities did not get a good response. However, as time went on, in the end the jam'iyah activities in the Muslim community received a quite positive response. It can even be said that the jam'iyah activities in the Muslim community are getting busier and more numerous. And apparently, this jam'íyah activity was enlivened by many women.

With the increasing number of jam'iyah activities in this community, especially if it turns out that those who follow it are women, of course it will be very good to be used as a place to convey da'wah. $D a$ 'wa about Islamic teachings which have been quite difficult to convey to women, will become easy with the jam'iyah activities in the community. Of course, the jam'íyah activities must be maximized as well as possible, so that the existence of the jam'iyah becomes really useful, especially for women.

The women who took part in this jam'íyah activity actually got a lot of useful knowledge that was not known before. This useful knowledge is of course related to the knowledge of Islamic teachings. The Islamic teachings conveyed in this jam'iayyah activity are part of the delivery of $d a^{\prime} w a$ to women. One of the teachings of Islam conveyed to these women, is the teaching of the holy book al-Qur'an. The teaching of the al-Qur'an to women is deemed necessary, because many of the Indonesian Muslim community, including women, are not very fluent in reading the al-Qur'an.

The teachings of the al-Qur'an delivered during the jam'iyah activities are very beneficial for women. The learning model and teaching of al-Qur'an in jam'íyah activities can be applied in various forms. One thing that is certain to do in jam'iyah activities, one of which is to read the AlQur'an together. Reading al-Qur'an together is considered quite effective, because someone who is not fluent enough to read the al-Qur'an can follow other friends. Another model that is commonly used in teaching al-Qur'an in jam'iyah activities is by following what the teacher reads. A teacher of Al-Qur'an recites one or several verses of the al-Qur'an, then followed by the women who are participating in this jam'íyah activity.

The teaching of al-Qur'an for women in jam'iyah activities is part of the delivery of $d a^{\prime} w a$ which is quite good to women. The existence of this jam'iyah activity is really maximized for the delivery of da'wah for women. The teaching of the al-Qur'an, in principle, is only one of the $d a^{\prime} w a h \mid$ materials that are conveyed to women. There are other da'wah materials that can be conveyed to them by maximizing the existence of jam'iyah activities in the Muslim community.

Other $d a^{\prime} w a$ material that is considered important for women, is material about teaching worship in accordance with Islamic teachings. The teaching of worship is just as important as the teaching of the Al-Qur'an. The delivery of worship materials for women, aims to ensure that women can perform worship properly. The material of worship that is often delivered to women in jam'iyah activities is usually material about ibadah mahdhah, such as thaharah, prayer, fasting and others. These services are worship that is carried out every day. Thus, the jam'iyah activities that are widely found in Indonesian Muslim communities are maximized as a place for $d a^{\prime} w a$ for women.

Maximizing jam'íyah activities as a place for da'wah for women is one part of the effort so that women can be empowered as well as possible. Because in Islamic teachings it is stated that men and women in principle have the same degree. ${ }^{8}$ The thing that makes the difference between men and women is the level of devotion to Allah swt. So, if men are allowed to study Islam, then women also have the same rights as men, namely learning Islam. The same thing is also related to the delivery of $d a^{\prime} w a$ material. That whoever the group, both men and women have the right to get $d a^{\prime} w a$ material. It's just that, especially for women, $d a^{\prime} w a$ material can be conveyed by maximizing jam'íyah activities in the Indonesian Muslim communities.

\footnotetext{
${ }^{8}$ Hamidah, Tutik. Fiqh Perempuan Berwawasan Keadilan Gender (Malang: UIN-Maliki Press, 2011), 7.
} 


\section{E. Conclusion}

The teachings of Islam brought by the prophet Muhammad saw actually taught Muslims that all human beings, whether male or female, are equal before Allah swt. The thing that distinguishes them is the level of their devotion to Allah Almighty. Therefore, every Muslim is ordered to compete in goodness. It's just that, in Muslim societies there are often imbalances between men and women. Women tend to lack movement, so it is often found that they do not understand Islamic teachings because of the frequency of the da'wa material that does not reach them. Through jam'iyah activities in the Muslim community, women will get a lot of knowledge about Islamic teachings. So that Muslim scholars must be able to maximize the jam'iyah activities as a place for da'wa for women. Many things can be done to maximize this jam'iyah activity. Among them is by giving teachings about the science of reading the al-Qur'an to them. Jam'iyah activities can also be maximized to teach women about the science of fiqh, such as taharah, șalat, and others.

\section{References}

Ahmad, Abdul Aziz. "Dakwah, Seni dan Teknologi Pembelajaran." Jurnal Dakwah Tabligh, n.d.: 76.

Bukhariy (al-), Muhammad bin Isma'il Abu 'Abdillah. Șaḥih al-Bukhäri. Vol. 6.9 vols. Damaskus: Dar Thouq al-Najah, 1422.

Hamidah, Tutik. Fiqh Perempuan Berwawasan Keadilan Gender. UIN-Maliki Press, 2011

Razy (al-), Fakhruddin. Al-Tafsir al-Kabir. Vol. 4. Beirut: Dar Ihya' al-Turath al-'Arabiy, 2000.

Siba'y (al-), Musthafa bin Husni. Al-Mar'ah bayn al-Fiqh wa al-Qānūn. Beirut: Dar al-Waraq li alNasyr wa al-Tawzi', 1999.

Syalby, Ro'uf. al-Da'wah al-Islamiyyah fi 'Ahdiha al-Makkiy. Al-Dauhah: Dar al-Qalam, 1982.

Syarifuddin, Ahmad, Mendidik Anak, Membaca dan Mencintai al-Qur'an. Jakarta: Gema Insani Press: 2004.

Zaidan, Abdul Karim. Ușul al-Da'wah. Beirut: Muassasah al-Risalah, 2001. 